\title{
Soil Loss due to Crop Harvesting in Usambara Mountains, Tanzania: The Case of Carrot, Onion and Potato
}

\author{
S. B. Mwango ${ }^{1^{\star}}$, B. M. Msanya ${ }^{1}$, P. W. Mtakwa ${ }^{1}$, D. N. Kimaro ${ }^{2}$, J. Deckers ${ }^{3}$, \\ J. Poesen ${ }^{3}$, S. Lilanga ${ }^{1}$ and R. Sanga ${ }^{1}$ \\ ${ }^{1}$ Department of Soil Science, Sokoine University of Agriculture, P.O. Box 3008 Chuo Kikuu, Morogoro, \\ Tanzania. \\ ${ }^{2}$ Department of Agricultural Engineering and Land Planning, Sokoine University of Agriculture, P.O. \\ Box 3003 Chuo Kikuu, Morogoro, Tanzania. \\ ${ }^{3}$ Department of Earth and Environmental Sciences, KU Leuven, Celestijnenlaan $200 \mathrm{E}$, \\ B-3001 Heverlee, Belgium.
}

Authors' contributions

This work was carried out in collaboration between all authors. Author SBM designed the study, wrote the protocol, conducted field work, performed statistical analysis, and wrote the first draft of the manuscript. Author BMM designed the study, conducted field work, managed the literature searches and edited drafts. Author PWM designed the study, conducted field work and edited drafts. Authors $D N K, J D$ and JP designed the study and edited drafts. Authors SL and RS conducted field and laboratory work. All authors read and approved the final manuscript

Article Information

DOI: $10.9734 /$ IJPSS/2015/12479 Editor(s):

(1) A. Mujib, Department of Botany, Hamdard University, India. Reviewers:

(1) Anonymous, University in Raipur, India. (2) Anonymous, University of Education, Winneba, Ghana. Complete Peer review History: http://www.sciencedomain.org/review-history.php?iid=651\&id=24\&aid=5963

\section{ABSTRACT}

Among the various soil erosion processes threatening sustainable agriculture, soil losses due to root, tuber and bulb harvesting are poorly documented, particularly in tropical environments. A study was thus conducted in two villages with contrasting agro-ecological conditions on Acrisols and Fluvisols in Western Usambara Mountains, Tanzania. The aim was to investigate the mass of soil and nutrients lost and the factors influencing variation of soil loss due to crop harvesting (SLCH) for Carrot (Daucus carrota), Onion (Allium cepa L.) and Potato (Solanum tuberosum L.) 
under low input agriculture. A total of 108 farm plots were sampled from the two villages. The mean $\mathrm{SLCH}$ values were significantly higher for carrot $(7.1 \mathrm{Mg} / \mathrm{ha} / \mathrm{harvest})$ than for onion (3.8 $\mathrm{Mg} / \mathrm{ha} / \mathrm{harvest}$ ) than for potatoes $(0.7 \mathrm{Mg} / \mathrm{ha} /$ harvest). Soil nutrient losses in $\mathrm{kg} / \mathrm{ha} / \mathrm{harvest}$ were higher for carrot than for onion and potatoes (e.g. $30 \mathrm{~N}, 0.1 \mathrm{P}, 1.5 \mathrm{~K}$ for carrot vs $6.3 \mathrm{~N}, 0.04 \mathrm{P}, 0.2$ $\mathrm{K}$ for onion) in Majulai village. SLCH was greater in Migambo (humid cold) than in Majulai (dry warm) for all the studied crops. Soil water content at harvest time played a significant $(P=.05)$ role in inducing SLCH for onion while bulk density for carrot, whereas for potato they were not significantly influenced by soil water content and bulk density. Soil texture played only a minor role to SLCH of the studied crops. The observed soil and nutrient losses in the current study are substantial and pose a challenge that calls for immediate attention to the harvesting practices in the study area. However, combating water erosion is far more urgent.

Keywords: Soil erosion; soil texture; soil water content; bulk density.

\section{INTRODUCTION}

Efforts to arrest soil erosion in Sub-Saharan countries including Tanzania have progressed very slowly for lack of adequate data and a link between specific soil erosion processes and the corresponding control measures [1]. Most of these efforts focus on water and tillage soil erosion, whereas significant soil masses that are lost from arable land during harvesting of root, tuber and bulb crops such as carrot (Daucus carrota), onion (Allium cepa L.), potato (Solanum tuberosum L.) and cassava (Manihot esculenta) are overlooked [2]. Soil sticking to the harvested crops that is exported from the field, and that is rarely returned to the field is referred to as soil loss due to crop harvesting (SLCH) [3,4].

While some studies on SLCH have been done under highly mechanized agriculture [5], only a single research by [4] in Uganda was conducted under low input agriculture. In their study, [4] investigated SLCH for cassava (Mannihot esculenta) and sweet potato (Ipomoea batatas) and the results showed considerable soil losses for cassava (3.4 Mg/ha/yr).

The present study investigated the magnitude of soil and nutrient losses due to harvesting of carrot (Daucus carrota), onion (Allium cepa L.) and potato (Solanum tuberosum L.) under traditional low-input agriculture in two contrasting agro-ecological settings in the Usambara Mountains, Tanzania on Acrisols and Fluvisols.

\section{MATERIALS AND METHODS}

\subsection{Study Area}

The current study was conducted in Migambo and Majulai villages, Western Usambara Mountains, Lushoto District, Tanzania (Fig. 1) located between coordinates $38^{\circ} 15^{\prime} \mathrm{E}$ to $38^{\circ} 24^{\prime}$ $\mathrm{E}$ and $4^{\circ} 34^{\prime} \mathrm{S}$ to $4^{\circ} 48^{\prime} \mathrm{S}$ with altitude ranging from 1400-1600 m.a.s.l. Migambo is humid cold with daily air temperature ranging from $12-17^{\circ} \mathrm{C}$ and mean annual precipitation of $1000 \mathrm{~mm}$ [6]. Majulai is dry warm with daily air temperature ranging between 16 and $21^{\circ} \mathrm{C}$ and mean annual precipitation of $700 \mathrm{~mm}$ [6]. The Usambara Mountains support a large population density of more than 102 persons $/ \mathrm{km}^{2}$ [7]. The dominant soils of the study area were mainly Acrisols on slopes and Fluvisols in valley bottoms.

The main land uses include cropland on slopes and valley bottoms, settlements on depressions, ridge summits and slopes. Vegetables such as carrots, onions, tomatoes, cabbages and peas are grown as sole crops in valleys (Table 1) under rain-fed or under traditional irrigation. Beans, maize, potatoes and fruits namely peaches, plums, pears, avocados, and bananas are grown on ridge slopes (Table 1) under rain-fed mixed farming. Potatoes are also grown in valleys as sole or intercropped with maize. Maize crop is mainly grown during short rain season while beans are grown during the long rain season. Potatoes, carrots, onions, cabbages, tomatoes and sweet peppers are sole crops usually grown twice a year during both long rain season (masika) and short rain season (vuli), but some vegetable crops such as cabbages, tomatoes and sweet peppers are also grown during offseason by traditional irrigation in few areas with water sources. Potatoes are harvested by hand hoe while carrots and onions are simply uprooted by hand pulling. Crops grown in the Usambara Mountains are sold in the local markets but are also exported outside the area to major towns in the surrounding plains: e.g. Dar es Salaam, Tanga, Arusha, Morogoro, Mombasa, Nairobi and Southern Sudan; thus the pressure on the fertile cropland is high. 


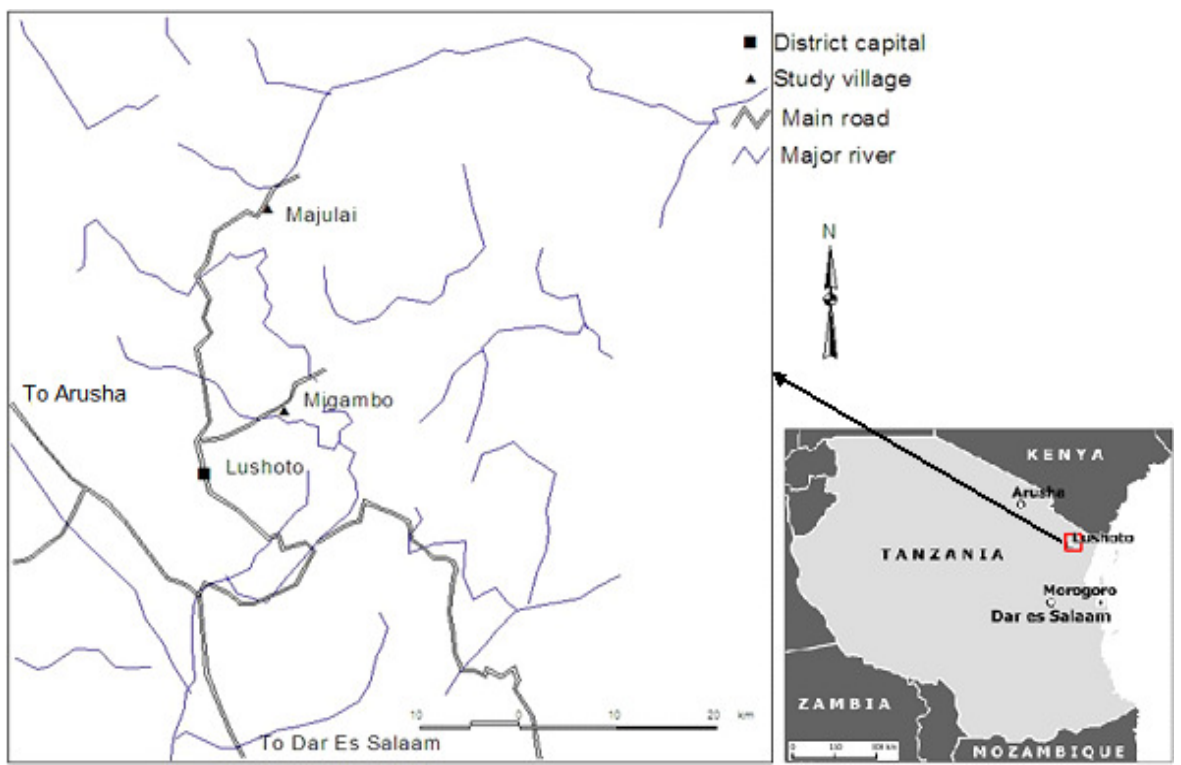

Fig. 1. The location map of Majulai and Migambo villages Lushoto District, Tanzania

\subsection{Data Collection}

In each village, 18 farms were selected per crop type. At each farm, harvesting was done in a quadrant of $1 \mathrm{~m}^{2}$ plot which was randomly selected. In each village, crop samples from 54 quadrants were collected making a total of 108 quadrants from the two villages. Clinging soil particles were removed from roots, bulbs and tubers by washing with clean water. The total dry soil mass was determined after evaporation of the wash water at $75-80^{\circ} \mathrm{C}$ and oven-drying overnight at $105^{\circ} \mathrm{C}$ [4]. At each sampling quadrant, one undisturbed topsoil sample was collected by Kopeck's core rings $\left(100 \mathrm{~cm}^{3}\right)$ for determination of soil moisture characteristics and bulk density (using oven dry at $105^{\circ} \mathrm{C}$ and pressure plate methods). Composite topsoil samples (from 10 subsamples randomly sampled at the farmers' plots at a depth between 0 and 30 $\mathrm{cm})$ were collected for soil fertility analysis. At each sampling point, land use, slope gradient and altitude were recorded. Soil loss due to crop harvesting was calculated as SLCH per unit of net fresh crop mass i.e. mass-specific SLCH (SLCHspec) and SLCH on an area-unit basis i.e. crop-specific SLCH (SLCHcrop) as defined by [3].

$\operatorname{SLCHspec}(\mathrm{kg} / \mathrm{kg})=\frac{M_{\mathrm{ds}}+\mathrm{M}_{\mathrm{rf}}}{M_{\text {crop }}}$
Where; $M_{d s}$ is the mass of oven-dry soil $(\mathrm{kg}), M_{r f}$ is the mass of rock fragments $(\mathrm{kg})=0, M_{\text {crop }}$ is the net crop mass $(\mathrm{kg})$.

$$
\text { SLCHcrop }(\mathrm{Mg} / \text { ha/harvest })=\mathrm{SLCH}_{\text {spec }} \times \mathrm{M}_{\mathrm{cy}}
$$

Where, $M_{c y}(M g / h a /$ harvest $)$ is the crop yield.

Nutrient loss $(\mathrm{kg} / \mathrm{ha} / \mathrm{harvest})=$ Nutrient Content

$$
\text { (g/kg soil) x SLCHcrop(MG/ha/harvest) }
$$

The nutrient content is expressed on oven-dry soil.

\subsection{Soil Analysis}

Soil analysis was done following the laboratory manual of [8]. Organic carbon (OC) was measured using the dichromate oxidation method; total nitrogen $(\mathrm{N})$ by Kjeldahl method; available phosphorus $(\mathrm{P})$, exchangeable calcium $\left(\mathrm{Ca}^{2+}\right)$ and exchangeable magnesium $\left(\mathrm{Mg}^{2+}\right)$ by atomic absorption spectrophotometer, exchangeable sodium $\left(\mathrm{Na}^{+}\right)$and exchangeable $\left(\mathrm{K}^{+}\right)$by Flame photometer; $\mathrm{pH}_{\text {water }}$ was determined by normal laboratory $\mathrm{pH}$ meter; bulk density by gravimetric method and soil texture by the hydrometer method.

\subsection{Statistical Analysis}

Descriptive statistics of the data was conducted and homogeneity of variances was tested, 
skewed data were log-normally transformed. Regressions analysis was performed using Minitab 14 software [9] to detect the relationships between SLCHspec and soil texture, soil water content and bulk density. SLCH variables were subjected to analysis of variance (ANOVA) using Genstat 14 software [10] to compare between crops. Least Significant Difference (LSD0.05) was used to detect mean differences.

\section{RESULTS AND DISCUSSION}

\subsection{Characteristics of the Selected Farm Plots in the Studied Villages}

The description of sampled farms and soil characteristics including the range of soil texture, SWC and bulk density and soil types at the farms during the survey in Majulai and Migambo villages are presented in Table 1.

\subsection{Effect of Soil Water Content, Bulk Density (BD) and Soil Texture on SLCH Variability}

\subsubsection{Onion}

The SLCH variability for onion with respect to SWC, BD and soil texture in Majulai and Migambo villages is presented in Table 2. Mean $\mathrm{SLCHspec}$ for onion was $0.1 \mathrm{~kg} / \mathrm{kg}$ ranging from 0.02 to $0.3 \mathrm{~kg} / \mathrm{kg}$ with a median of $0.1 \mathrm{~kg} / \mathrm{kg}$ in Majulai. The mean SLCHspec in Migambo was $0.4 \mathrm{~kg} / \mathrm{kg}$ ranging from 0.2 to $0.6 \mathrm{~kg} / \mathrm{kg}$ and a median of $0.5 \mathrm{~kg} / \mathrm{kg}$. SLCHcrop ranged from 1.0 to $4.0 \mathrm{Mg} / \mathrm{ha} / \mathrm{harvest}$ with average of 2.8 $\mathrm{Mg} / \mathrm{ha} / \mathrm{harvest}$ and had a median of 3.0 $\mathrm{Mg} / \mathrm{ha} /$ harvest in Majulai; and ranged from 2.2 to $12.2 \mathrm{Mg} / \mathrm{ha} / \mathrm{harvest}$ with average of 5.2 $\mathrm{Mg} / \mathrm{ha} /$ harvest and a median of 5.1 $\mathrm{Mg} / \mathrm{ha} /$ harvest in Migambo. Bulk density (BD) had positive influence at $5 \%$ level $\left(R^{2}=0.53, P\right.$ $=.03$ ) on SLCHspec for onion in Majulai whereas in Migambo it had no influence (Table 2). Soil texture and soil water content (SWC) at harvest played only a minor role on the variability of $\mathrm{SLCH}$ for onion in both villages. The low correlation between SLCHspec for onion with SWC and soil texture within the studied villages is partly due to the small variations of SWC at harvest, sand, clay and silt contents because of the slight variations of landform of the farms sampled (Table 1). A similar observation was reported by [2] and [3] where small variations in sand and clay contents and SWC that characterized most farms sampled were the reason for the poor correlations between SLCH with texture and SWC.

Table 3 presents the SLCH variability for onion when the results from the two villages were combined. The following variations of SLCHspec for onion with respect to SWC, soil texture and bulk density were observed. Soil water content at harvest had positive influence $\left(R^{2}=0.39, P=\right.$ .006) on SLCHspec (Table 3), whereas sand, silt, clay and $\mathrm{BD}$ had weak correlations with $\mathrm{SLCHspec}$ for onion. Likewise when the factors were subjected to multiple regressions, SWC significantly $(\mathrm{P}<.001)$ correlated with $\mathrm{SLCHspec}$, and all the factors in combination could explain about $79 \%$ of the variations of SLCHspec for onion (Table 3). The positive correlation of SWC with SLCHspec for onion can be explained by the variation of soil moisture contents between the two villages where Migambo village with a humid climate had higher soil moisture content than Majulai village which is has dry climate (Table 1). A similar observation was reported by [11] where rainfall depth was found to influence SLCH of sugar beets.

\subsubsection{Carrot}

The SLCH variability for carrot with respect to SWC, BD and soil texture in Majulai and Migambo villages is presented in Table 2. Mean $\mathrm{SLCHspec}$ for carrot was $0.3 \mathrm{~kg} / \mathrm{kg}$ ranging from 0.2 to $0.6 \mathrm{~kg} / \mathrm{kg}$ and a median of 0.3 $\mathrm{Mg} / \mathrm{ha} / \mathrm{harvest}$ in Majulai, while in Migambo the mean SLCHspec was $0.4 \mathrm{~kg} / \mathrm{kg}$ and ranged from 0.2 to $0.8 \mathrm{~kg} / \mathrm{kg}$ and a median of $0.3 \mathrm{~kg} / \mathrm{kg}$. SLCHcrop ranged from 4.0 to 13.0 $\mathrm{Mg} / \mathrm{ha} /$ harvest with a mean $7.0 \mathrm{Mg} / \mathrm{ha} /$ harvest and a median of $7.0 \mathrm{Mg} / \mathrm{ha} /$ harvest in Majulai and ranged from 2.8 to $23.0 \mathrm{Mg} / \mathrm{ha} /$ harvest with a mean of $7.1 \mathrm{Mg} / \mathrm{ha} /$ harvest and a median of 5.5 $\mathrm{Mg} / \mathrm{ha} /$ harvest in Migambo. Bulk density $\left(\mathrm{R}^{2}=\right.$ $0.84, P<.001) S W C$ at $\left(R^{2}=0.71, P=.004\right)$ and $\%$ clay at $\left(R^{2}=0.84, P=.001\right)$ had positive influences on SLCHspec for carrot whereas \% sand at $\left(R^{2}=0.83, P=.001\right)$ and $\%$ silt at $\left(R^{2}=\right.$ $0.84, \mathrm{P}<.001)$ had a negative influence in Migambo (Table 3); this agreed with the study by $[12,2]$ where gravimetric soil moisture content and \% clay were positively related to SLCHspec. On the other hand, in Majulai \% silt had a positive influence $\left(R^{2}=0.44, P=.05\right)$ on $\mathrm{SLCH}$ while BD, SWC, \% clay and \% sand had a minor influence. The correlation of SWC and BD with $\mathrm{SLCHspec}$ for carrot in Migambo village can be explained by the higher SWC at harvesting time in Migambo than in Majulai village which 
facilitated soil to stick on the surface of carrot roots. Similarly the correlation between SLCHspec and SWC was explained by [4] to be influenced by the tendency of moist soil to stick on roots more than dry soil.

Table 3 presents the SLCH variability for carrot when the results from the two villages were combined. The variability of SLCHspec for carrot with respect to SWC, soil texture and $\mathrm{BD}$ revealed weak $(P=.05)$ correlations with SLCHspec. However, when the factors were subjected to multiple regressions BD significantly $(P=.01)$ correlated with SLCHspec for carrot, and all the factors in combination could explain about $79 \%$ of the variations of SLCHspec for carrot (Table 3). This can directly be associated with the rough and kinked morphology of carrot, thus the higher the bulk density more the soil is expected to stick on the carrot roots.

\subsubsection{Potato}

The SLCH variability for potato with respect to SWC, BD and soil texture is presented in Tables 2 and 3. Mean SLCHspec for potato was 0.1 $\mathrm{kg} / \mathrm{kg}$ and ranged from 0.05 to $0.14 \mathrm{~kg} / \mathrm{kg}$ with a median of $0.1 \mathrm{~kg} / \mathrm{kg}$ in Majulai; the mean SLCHspec in Migambo was $0.1 \mathrm{~kg} / \mathrm{kg}$ and ranged from 0.05 to $0.20 \mathrm{~kg} / \mathrm{kg}$ with a median of $0.06 \mathrm{~kg} / \mathrm{kg}$. SLCHcrop ranged from 0.7 to 2.0 $\mathrm{Mg} / \mathrm{ha} / \mathrm{harvest}$ with a mean of $1.1 \mathrm{Mg} / \mathrm{ha} /$ harvest and a median of $1.1 \mathrm{Mg} / \mathrm{ha} / \mathrm{harvest}$ in Majulai and ranged from 0.23 to $1.20 \mathrm{Mg} / \mathrm{ha} /$ harvest with a mean of $0.5 \mathrm{Mg} / \mathrm{ha} /$ harvest and a median of 0.5 $\mathrm{Mg} / \mathrm{ha} /$ harvest in Migambo. SLCHspec for potato was not significantly $(P=.05)$ influenced by SWC, BD and soil texture at harvesting time. Likewise when the factors were combined in multiple regressions they did not significantly $(P$ $=.05$ ) correlated with SLCHspec, and they could only explain about $24 \%$ of the variations of SLCHspec for potato (Table 3).

\subsection{Differences in SLCH between Crops in Majulai and Migambo Villages}

From Table 4 it can clearly be seen that SLCHspec and SLCHcrop for carrot were significantly $(P=.05)$ higher for onion and potato. Similarly for crop yields, this followed the same trend. When considering the effect of villages, it is clear that the SLCHspec and SLCHcrop values per harvest for carrot were significantly $(P=.05)$ higher than for onion and potato in Majulai village; likewise for Migambo village, the trend was the same. On the other hand, yield for onion was significantly $(P=.05)$ higher than for carrot and potato in Majulai village, while in Migambo village, yield for carrot was higher than for onion and potato. The higher values of SLCH variable for carrot can be explained by the higher gross yield of carrots than the onion and potato as well as its rough and kinked morphology, thus more soil is expected to stick on the rougher root skin of carrots compared to the smoother potato tubers and onion bulbs. This observation is also supported by [4] who reported that the higher $\mathrm{SLCH}$ variables in cassava than potato were associated with higher gross yield and rough morphology of cassava roots. On the other hand smoother morphology of potato tubers as compared with carrot and onions could be the reason why SLCHspec for potato was not significantly correlated with studied SLCH variables. It is worth to note that the studied crops are usually cultivated twice a year during long rain season and short rain season.

\subsection{Soil Nutrient Losses Associated with SLCH of the Studied Crops}

Soil nutrient losses due to crop harvesting are presented in Table 5. Differences in soil nutrient loss between crops and villages can be attributed to the differences in average crop yield (Table 4) and the inherent nutrient status of the topsoil (Table 6). Generally, nutrient losses were higher in Migambo (humid cold) than in Majulai (dry warm) with the order of magnitude such that $\mathrm{OC}$ $>$ Total $\mathrm{N}>\mathrm{Ca}>\mathrm{Mg}>\mathrm{K}>\mathrm{Na}>\mathrm{P}$. Carrot harvesting had the highest soil nutrient losses (Table 5) where the OC, N, P, K, Ca, Mg and $\mathrm{Na}$ losses were respectively $365,30,0.1,2,19,4$ and $0.7 \mathrm{~kg} / \mathrm{ha} /$ harvest in Majulai and 423, 32, $0.1,0.8,16,3$ and $0.4 \mathrm{~kg} / \mathrm{ha} /$ harvest in Migambo village. The magnitude of soil and nutrient losses observed is considerable such that with time soils will be depleted and this will pose severe nutrient imbalances. A study by [6] in Migambo village reported respectively total $\mathrm{N}, \mathrm{P}$ and $\mathrm{K}$ losses due to interill and rill erosion of about 248, 31 and $3 \mathrm{~kg} / \mathrm{ha} / y e a r$. In absolute terms the reported losses in the current study particularly of $\mathrm{OC}$, Total $\mathrm{N}, \mathrm{Ca}, \mathrm{Mg}$ and $\mathrm{K}$ are alarming. However when compared with soil and nutrient losses due to water erosion, controlling water erosion is by far more urgent. Usually crop residues are left on fields and some farmers replenish their farm plots by adding small doses of Urea and di-ammonium phosphate (DAP) (about 10 to $50 \mathrm{~kg} / \mathrm{ha}$ ) and yet others do not use any fertilizer. 
Table 1. Characteristics of the studied villages and the selected farm plots

\begin{tabular}{|c|c|c|c|c|c|c|c|c|c|c|c|c|c|}
\hline $\begin{array}{l}\text { Village/ } \\
\text { Crop }\end{array}$ & AEZ & $\begin{array}{l}\text { Altitude } \\
\text { (m. a.s.l) }\end{array}$ & $\begin{array}{l}\text { Slope } \\
\%\end{array}$ & $\begin{array}{l}\text { Land } \\
\text { form }\end{array}$ & $\begin{array}{l}\text { SWC } \\
(\%)\end{array}$ & $\begin{array}{l}\text { FC } \\
\text { (\%) }\end{array}$ & $\begin{array}{l}\text { PWP } \\
(\%)\end{array}$ & $\begin{array}{l}\text { BD } \\
\left(\mathrm{g} / \mathrm{cm}^{3}\right)\end{array}$ & $\%$ clay & $\%$ silt & $\%$ sand & $\begin{array}{l}\text { Soil } \\
\text { texture }\end{array}$ & $\begin{array}{l}\text { Soil type } \\
\text { (FAO } \\
\text { WRB) }\end{array}$ \\
\hline Majulai & $\begin{array}{l}\text { Dry and } \\
\text { warm } \\
\text { zone }\end{array}$ & & & & & & & & & & & & \multirow{4}{*}{$\begin{array}{l}\text { Haplic and } \\
\text { Gleyic } \\
\text { Fluvisols \& } \\
\text { Stagnic } \\
\text { Acrisols } \\
\text { Chromic } \\
\text { Acrisols }\end{array}$} \\
\hline Onion & & 1355-1401 & $0.5-1$ & V \& TS & 30 & 30 & 14 & 1.3 & $32(27-41)$ & $5(3-7)$ & $\begin{array}{l}63(56- \\
70)\end{array}$ & SCL & \\
\hline Carrot & & 1530-1719 & $1-2$ & V \& TS & 32 & $30-45$ & $14-20$ & 1.1 & $36(31-45)$ & $10(8-11)$ & $54(46-58)$ & $\begin{array}{l}\text { SCL } \\
\& C\end{array}$ & \\
\hline Potato & & 1383-1633 & $30-55$ & LS & 38 & $30-45$ & $14-20$ & 1.3 & $41(29-57)$ & $9(7-11)$ & $50(36-62)$ & $\begin{array}{l}\text { C, SC \& } \\
\text { SCL }\end{array}$ & \\
\hline Migambo & $\begin{array}{l}\text { Humid } \\
\text { and cold } \\
\text { zone }\end{array}$ & & & & & & & & & & & & \\
\hline Onion & & $1572-1620$ & $1-3$ & $V \& T S$ & 83 & 30 & 14 & 1.3 & $\begin{array}{l}30(29- \\
31)\end{array}$ & $8(5-11)$ & $63(60-62)$ & SCL & $\begin{array}{l}\text { Mollic } \\
\text { Fluvisols }\end{array}$ \\
\hline Carrot & & 1603-1654 & $0.5-1$ & V & 58 & $25-33$ & $5-16$ & 0.9 & $25(21-32)$ & $15(9-19)$ & $60(59-60)$ & $\begin{array}{l}\text { SL \& } \\
\text { SCL }\end{array}$ & $\begin{array}{l}\text { Mollic } \\
\text { Fluvisols }\end{array}$ \\
\hline Potato & & $1552-1576$ & $20-25$ & $\begin{array}{l}\text { MS \& } \\
\text { LS }\end{array}$ & 85 & $31-45$ & $15-20$ & 1.2 & $44(43-45)$ & $10(9-11)$ & $47(46-48)$ & $\begin{array}{l}\text { SCL } \\
\& C\end{array}$ & $\begin{array}{l}\text { Haplic } \\
\text { Acrisols }\end{array}$ \\
\hline
\end{tabular}


Table 2. Relationship between SLCHspec ( $\mathrm{Y}, \mathrm{kg} / \mathrm{kg}$ ) and gravimetric soil water content (SWC \% $\mathrm{g} / \mathrm{g}$ ) at harvesting time, BD $\left(\mathrm{g} / \mathrm{cm}^{3}\right), \%$ clay, $\%$ silt and $\%$ sand for the studied crops in Majulai and Migambo village

\begin{tabular}{|c|c|c|c|c|c|c|c|}
\hline \multirow[t]{2}{*}{ Measured variable } & \multicolumn{4}{|c|}{ Majulai } & \multicolumn{3}{|l|}{ Migambo } \\
\hline & $\mathbf{n}$ & $\ln Y$ & $\mathbf{R}^{2}$ & $P$ & $\ln Y$ & $\mathbf{R}^{2}$ & $P$ \\
\hline \multicolumn{8}{|l|}{ Onion } \\
\hline Clay (\%) & 18 & $-0.12-0.64 \ln X 1$ & 0.028 & 0.67 & $-1.4+0.16 \ln X 1$ & 0.000 & 0.98 \\
\hline Sand (\%) & 18 & $-3.53+0.0189 \times 2$ & 0.043 & 0.59 & $-24.8+5.77 \ln X 2$ & 0.224 & 0.20 \\
\hline Silt (\%) & 18 & $-0.82-0.993 \ln X 3$ & 0.249 & 0.17 & $0.491-0.709 \ln X 3$ & 0.232 & 0.19 \\
\hline SWC (\%) & 18 & $-1.36-0.0325 \times 4$ & 0.152 & 0.30 & 3.0- $0.89 \ln X 4$ & 0.003 & 0.89 \\
\hline $\mathrm{BD}\left(\mathrm{g} \mathrm{cc}^{-1}\right)$ & 18 & $-4.75+0.858 \ln \times 5$ & 0.526 & 0.03 & $-0.073-3.14 \ln \times 5$ & 0.156 & 0.29 \\
\hline \multicolumn{8}{|l|}{ Carrot } \\
\hline Clay (\%) & 18 & $3.71-1.36 \ln X 1$ & 0.328 & 0.11 & $-9.66+2.69 \ln X 1$ & 0.840 & 0.001 \\
\hline Sand (\%) & 18 & $-3.41+0.0424 \ln X 2$ & 0.329 & 0.11 & $205-50.3 \ln X 2$ & 0.829 & 0.001 \\
\hline Silt (\%) & 18 & $-7.37+2.68 \ln X 3$ & 0.435 & 0.05 & $2.97-1.5 \ln X 3$ & 0.844 & 0.000 \\
\hline SWC (\%) & 18 & $-1.34+0.0063 \times 4$ & 0.009 & 0.81 & $-13.2+3.0 \ln X 4$ & 0.710 & 0.004 \\
\hline $\mathrm{BD}\left(\mathrm{g} \mathrm{cm}^{-3}\right)$ & 18 & $-0.963-1.98 \ln \times 5$ & 0.174 & 0.26 & $-0.656+3.0 \ln \times 5$ & 0.844 & 0.000 \\
\hline \multicolumn{8}{|l|}{ Potato } \\
\hline Clay (\%) & 18 & $-0.80-0.453 \ln X 1$ & 0.148 & 0.31 & $3.7-1.66 \ln X 1$ & 0.004 & 0.87 \\
\hline Sand (\%) & 18 & $-3.10+0.0125 X 2$ & 0.165 & 0.28 & $-17.6+3.9 \ln X 2$ & 0.021 & 0.71 \\
\hline Silt (\%) & 18 & $-1.19-0.588 \ln X 3$ & 0.110 & 0.38 & $-1.53-0.45 \ln X 3$ & 0.006 & 0.84 \\
\hline SWC (\%) & 18 & $-3.34+0.0232 X 4$ & 0.107 & 0.39 & $-3.4+0.19 \ln X 4$ & 0.000 & 0.97 \\
\hline $\mathrm{BD}\left(\mathrm{g} \mathrm{cc}^{-1}\right)$ & 18 & $-1.96-1.80 \ln \times 5$ & 0.020 & 0.72 & $-2.49-0.29 \ln X 5$ & 0.001 & 0.93 \\
\hline
\end{tabular}
Where $X 1, X 2, X 3, X 4$ and $X 5$ are $\%$ clay, \% sand, \% silt, \% SWC and BD respectively

Table 3. Relationship between SLCHspec $(Y, \mathrm{~kg} / \mathrm{kg})$ and gravimetric soil water content (SWC \% $\mathrm{g} / \mathrm{g})$ at harvesting time, $\mathrm{BD}\left(\mathrm{g} / \mathrm{cm}^{3}\right), \%$ clay, $(\%)$ silt and \% sand as $X$ variables for the studied villages when combined

\begin{tabular}{|c|c|c|c|c|}
\hline Measured variable & $\mathbf{n}$ & $\ln Y$ & $\mathbf{R}^{2}$ & $\boldsymbol{P}$ \\
\hline \multicolumn{5}{|l|}{ Onion } \\
\hline Clav (\%) & 36 & $4.98-1.93 \ln X 1$ & 0.079 & 0.26 \\
\hline Sand $(\%)$ & 36 & $-8.9+1.73 \ln X 2$ & 0.031 & 0.49 \\
\hline Silt (\%) & 36 & $-2.24+0.35 \ln X 3$ & 0.023 & 0.55 \\
\hline SWC (\%) & 36 & $-5.67+1.04 \ln X 4$ & 0.390 & 0.006 \\
\hline $\operatorname{BD}\left(\mathrm{g} \mathrm{cc}^{-1}\right)$ & 36 & $-1.92+1.1 \ln \times 5$ & 0.005 & 0.78 \\
\hline \multirow{2}{*}{\multicolumn{5}{|c|}{$\begin{array}{l}\ln Y=-1239+115 \ln X 1+193 \ln X 2+14.6 \ln X 3+2.26 \ln X 4+50.7 \ln X 5 \\
\text { Carrot }\end{array}$}} \\
\hline & & & & \\
\hline Clay (\%) & 36 & $-1.92+0.248 \ln X 1$ & 0.017 & 0.60 \\
\hline Sand $(\%)$ & 36 & $-7.13+1.5 \ln X 2$ & 0.085 & 0.24 \\
\hline Silt (\%) & 36 & $0.634-0.689 \ln X 3$ & 0.181 & 0.08 \\
\hline SWC (\%) & 36 & $-2.94+0.496 \ln X 4$ & 0.129 & 0.14 \\
\hline $\mathrm{BD}\left(\mathrm{g} \mathrm{cc}^{-1}\right)$ & 36 & $-1.07+0.983 \ln \times 5$ & 0.121 & 0.16 \\
\hline \multicolumn{3}{|c|}{$\ln Y=-122+9.1 \ln X 1+14.7 \ln X 2+9.96 \ln X 3+1.74 \ln X 4+12.2 \ln X 5$} & 0.793 & 0.001 \\
\hline \multicolumn{5}{|l|}{ Round potato } \\
\hline Clay (\%) & 36 & $-0.73-0.475 \ln X 1$ & 0.047 & 0.39 \\
\hline Sand (\%) & 36 & $-4.67+0.561 \ln X 2$ & 0.040 & 0.42 \\
\hline Silt (\%) & 36 & $-1.22-0.58 \ln X 3$ & 0.039 & 0.43 \\
\hline SWC (\%) & 36 & $-2.34-0.04 \ln X 4$ & 0.001 & 0.88 \\
\hline $\mathrm{BD}\left(\mathrm{acc}^{-1}\right)$ & 36 & $-2.54+0.16 \ln \times 5$ & 0.001 & 0.91 \\
\hline \multicolumn{3}{|c|}{$\ln Y=23-3.37 \ln X 1-2.6 \ln X 2-1.53 \ln X 3+0.19 \ln X 4-1.09 \ln X 5$} & 0.237 & 0.61 \\
\hline
\end{tabular}

Where $X 1, X 2, X 3, X 4$ and $X 5$ are \% clay, \% sand, \% silt, \% SWC and BD respectively 
Table 4. Impact of the studied crops on mean crop yield, SLCHspec and SLCHcrop in Majulai and Migambo villages

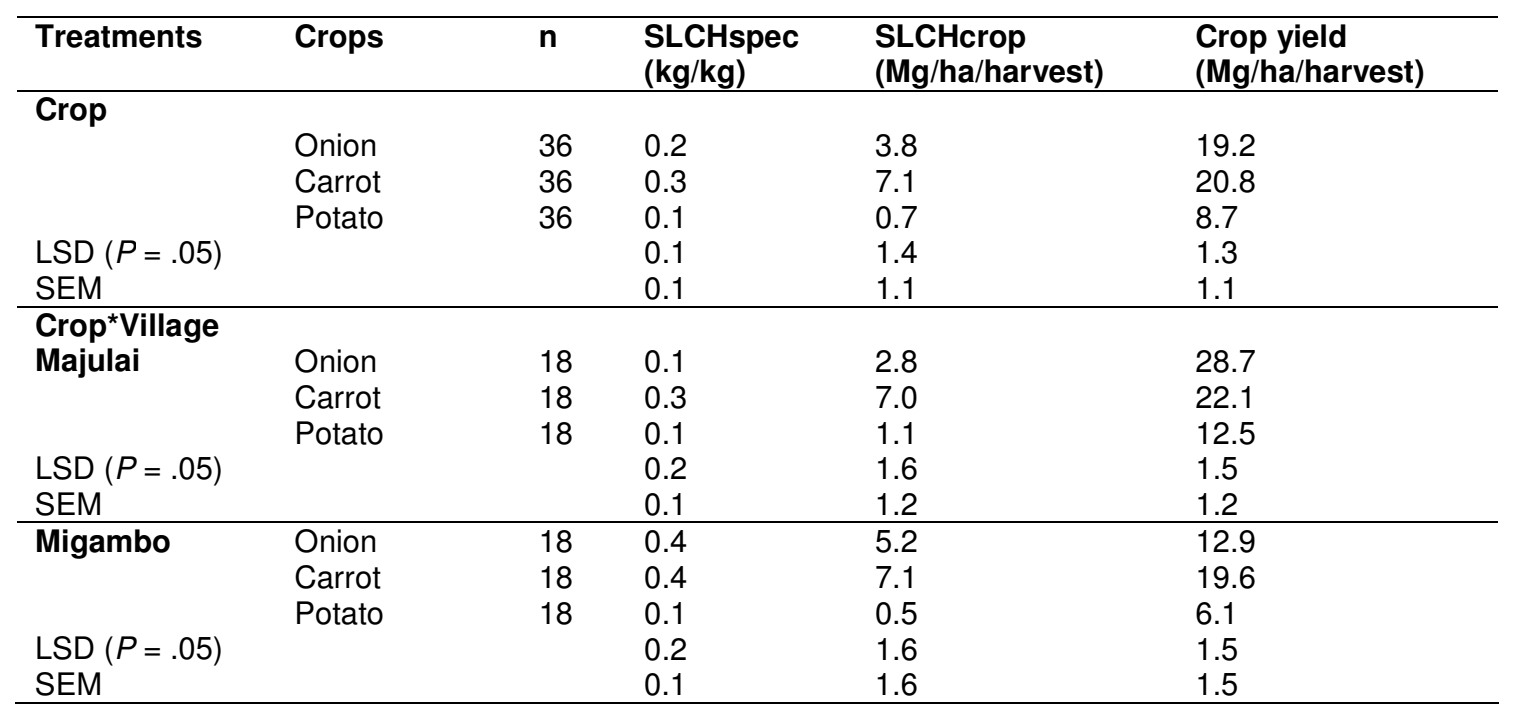

Table 5. Estimates of soil nutrient loss ( $\mathrm{kg} / \mathrm{ha} / \mathrm{harvest})$ and STDEV in brackets for each crop in two villages

\begin{tabular}{|c|c|c|c|c|c|c|c|c|c|}
\hline & Crop & $\mathbf{n}$ & OC & Total $\mathbf{N}$ & $\mathbf{P}$ & $\mathrm{K}^{+}$ & $\mathrm{Ca}^{2+}$ & $\mathrm{Mg}^{2+}$ & $\mathrm{Na}^{+}$ \\
\hline \multicolumn{10}{|l|}{ Majulai } \\
\hline & Onion & 18 & $\begin{array}{l}21 \\
(20)\end{array}$ & $\begin{array}{l}6 \\
(4)\end{array}$ & $\begin{array}{l}0.04 \\
(0.03)\end{array}$ & $\begin{array}{l}0.3 \\
(0.1)\end{array}$ & $\begin{array}{l}4 \\
(1.5)\end{array}$ & $\begin{array}{l}1.1 \\
(0.4)\end{array}$ & $\begin{array}{l}0.2 \\
(0.1)\end{array}$ \\
\hline & Carrot & 18 & $\begin{array}{l}365 \\
(191)\end{array}$ & $\begin{array}{l}30 \\
(16)\end{array}$ & $\begin{array}{l}0.09 \\
(0.07)\end{array}$ & $\begin{array}{l}1.5 \\
(0.8)\end{array}$ & $\begin{array}{l}19 \\
(12)\end{array}$ & $\begin{array}{l}3.9 \\
(2.2)\end{array}$ & $\begin{array}{l}0.7 \\
(0.3)\end{array}$ \\
\hline & Potato & 18 & $\begin{array}{l}29 \\
(12)\end{array}$ & $\begin{array}{l}3 \\
(1)\end{array}$ & $\begin{array}{l}0.01 \\
(0.004)\end{array}$ & $\begin{array}{l}0.3 \\
(0.3)\end{array}$ & $\begin{array}{l}2 \\
(0.8)\end{array}$ & $\begin{array}{l}0.5 \\
(0.2)\end{array}$ & $\begin{array}{l}0.1 \\
(0.07)\end{array}$ \\
\hline \multicolumn{10}{|l|}{ Migambo } \\
\hline & Onion & 18 & $\begin{array}{l}134 \\
(101)\end{array}$ & $\begin{array}{l}14 \\
(11)\end{array}$ & $\begin{array}{l}0.06 \\
(0.02)\end{array}$ & $\begin{array}{l}1.3 \\
(1.1)\end{array}$ & $\begin{array}{l}10 \\
(6.5)\end{array}$ & $\begin{array}{l}3.0 \\
(1.5)\end{array}$ & $\begin{array}{l}0.4 \\
(0.3)\end{array}$ \\
\hline & Carrot & 18 & $\begin{array}{l}423 \\
(113)\end{array}$ & $\begin{array}{l}32 \\
(11)\end{array}$ & $\begin{array}{l}0.07 \\
(0.06)\end{array}$ & $\begin{array}{l}0.8 \\
(0.6)\end{array}$ & $\begin{array}{l}16 \\
(14)\end{array}$ & $\begin{array}{l}2.8 \\
(2.7)\end{array}$ & $\begin{array}{l}0.4 \\
(0.3)\end{array}$ \\
\hline & Potato & 18 & $\begin{array}{l}21 \\
(11)\end{array}$ & $\begin{array}{l}2 \\
(0.9)\end{array}$ & $\begin{array}{l}0.003 \\
(0.002)\end{array}$ & $\begin{array}{l}0.1 \\
(0.8)\end{array}$ & $\begin{array}{l}1 \\
(0.6)\end{array}$ & $\begin{array}{l}0.2 \\
(0.1)\end{array}$ & $\begin{array}{l}0.01 \\
(0.007)\end{array}$ \\
\hline
\end{tabular}

Table 6. Average topsoil $(0-30 \mathrm{~cm})$ nutrients status $(\mathrm{g} / \mathrm{kg})$ with STDEV in brackets for the farm plots surveyed

\begin{tabular}{|c|c|c|c|c|c|c|c|c|c|}
\hline & Crop & $n$ & OC & Total N & $\mathbf{P}$ & $\overline{\mathrm{K}^{+}}$ & $\mathrm{Ca}^{2+}$ & $\mathrm{Mg}^{2+}$ & $\mathrm{Na}^{+}$ \\
\hline \multicolumn{10}{|l|}{ Majulai } \\
\hline & Onion & 18 & $\begin{array}{l}22 \\
(18)\end{array}$ & $\begin{array}{l}3 \\
(2)\end{array}$ & $\begin{array}{l}0.01 \\
(0.007)\end{array}$ & $\begin{array}{l}0.1 \\
(0.6)\end{array}$ & $\begin{array}{l}1.9 \\
(1.0)\end{array}$ & $\begin{array}{l}0.6 \\
(0.3)\end{array}$ & $\begin{array}{l}0.03 \\
(0.01)\end{array}$ \\
\hline & Carrot & 18 & $\begin{array}{l}33 \\
(17)\end{array}$ & $\begin{array}{l}3 \\
(1.5)\end{array}$ & $\begin{array}{l}0.01 \\
(0.007)\end{array}$ & $\begin{array}{l}0.1 \\
(0.06)\end{array}$ & $\begin{array}{l}1.6 \\
(0.9)\end{array}$ & $\begin{array}{l}0.4 \\
(0.2)\end{array}$ & $\begin{array}{l}0.03 \\
(0.01)\end{array}$ \\
\hline & Potato & 18 & $\begin{array}{l}26 \\
(12)\end{array}$ & $\begin{array}{l}2 \\
(0.5)\end{array}$ & $\begin{array}{l}0.003 \\
(0.001)\end{array}$ & $\begin{array}{l}0.1 \\
(0.05)\end{array}$ & $\begin{array}{l}0.9 \\
(0.7)\end{array}$ & $\begin{array}{l}0.3 \\
(0.1)\end{array}$ & $\begin{array}{l}0.03 \\
(0.01)\end{array}$ \\
\hline \multicolumn{10}{|c|}{ Migambo } \\
\hline & Onion & 18 & $\begin{array}{l}17.1 \\
(7.5)\end{array}$ & $\begin{array}{l}2 \\
(1.6)\end{array}$ & $\begin{array}{l}0.07 \\
(0.03)\end{array}$ & $\begin{array}{l}0.6 \\
(0.4)\end{array}$ & $\begin{array}{l}2.9 \\
(1.1)\end{array}$ & $\begin{array}{l}0.6 \\
(0.4)\end{array}$ & $\begin{array}{l}0.3 \\
(0.1)\end{array}$ \\
\hline & Carrot & 18 & $\begin{array}{l}52.3 \\
(24.5)\end{array}$ & $\begin{array}{l}4 \\
\text { (2) }\end{array}$ & $\begin{array}{l}0.004 \\
(0.001)\end{array}$ & $\begin{array}{l}0.1 \\
(0.08)\end{array}$ & $\begin{array}{l}1.9 \\
(1.0)\end{array}$ & $\begin{array}{l}0.4 \\
(0.1)\end{array}$ & $\begin{array}{l}0.04 \\
(0.02)\end{array}$ \\
\hline & Potato & 18 & $\begin{array}{l}31.8 \\
(14.3)\end{array}$ & $\begin{array}{l}3 \\
(1.4)\end{array}$ & $\begin{array}{l}0.003 \\
(0.001)\end{array}$ & $\begin{array}{l}0.2 \\
(0.1)\end{array}$ & $\begin{array}{l}2.2 \\
(1.0)\end{array}$ & $\begin{array}{l}0.3 \\
(0.2)\end{array}$ & $\begin{array}{l}0.02 \\
(0.01)\end{array}$ \\
\hline
\end{tabular}


Farmers in Usambara Mountains usually clean their harvested crops in river streams and transport them to the local and markets in Dar es Salaam, Tanga, Arusha, Morogoro, Mombasa, Nairobi, Southern Sudan and other nearby towns or sometimes harvested crops are stored in farmers' compounds before transportation. Still some farmers do not clean their harvested crops i.e. soon after harvesting the crops with soil particles are packed and transported to the aforementioned markets, thus most of SLCH are dumped in these markets and in river streams when crops are cleaned and some are lost during storage and transportation. Therefore soil and nutrient lost as a result of these kinds of harvesting practices are rarely returned back to the cropland where the crop was grown. On the other hand cleaning of harvested crops in river streams contributes to extra sediment load, and hence pollution of the river water which may cause negative down-stream effects (e.g. flooding, siltation in channels and reservoirs).

\subsection{Soil Losses Observed in the Current Study as Compared to the Reported Losses due to Other Soil Erosion Processes}

When compared to soil losses by other soil erosion processes such as interill, rill and tillage (Table 7), it is obvious that the reported losses in this study should not be underrated. According to severity classes for interill and rill erosion as reported by [13], the soil losses observed in this study i.e. 5.2 for onion and $7.1 \mathrm{Mg} / \mathrm{ha} /$ harvest for carrot fall under moderate erosion and 1.1 $\mathrm{Mg} / \mathrm{ha} / \mathrm{harvest}$ for potato is classified as mild erosion, taking into consideration the two cropping cycles in a year. The current study had relatively low SLCH values when compared with the works by [14] and [12] in Belgium who reported the mean SLCH of $15.8 \mathrm{Mg} / \mathrm{ha} /$ harvest for carrot and $3.2 \mathrm{Mg} / \mathrm{ha} / \mathrm{harvest}$ for potato respectively, while in Uganda, [4] reported a $\mathrm{SLCH}$ of $3.4 \mathrm{Mg} / \mathrm{ha} /$ harvest for cassava.

Table 7. Reported soil losses due to crop harvesting, water and tillage erosion as compared to SLCH in the Usambara Mountains obtained in this study

\begin{tabular}{|c|c|c|c|c|c|}
\hline Data type & Country & $\begin{array}{l}\text { Soil loss } \\
\text { Mg/ha/year }\end{array}$ & $\begin{array}{l}\text { SLCHcrop (Mg/ha } \\
\text { /harvest) (min-max) }\end{array}$ & $\begin{array}{l}\text { Measureme } \\
\text { nt period }\end{array}$ & Source \\
\hline \multicolumn{6}{|c|}{ SLCH under high-input mechanized agriculture } \\
\hline Carrot & Belgium & & $15.8(0.5-65.5)$ & 2001-2002, & [14] \\
\hline Carrot & Russia & & $2.5(1.8-3.4)$ & 1985 & [15] \\
\hline Potato & Belgium & & $3.2(0.2-21.4)$ & $2002-2003$ & [12] \\
\hline Potato & Germany & & $6.7(1.0-13.4)$ & 1996-2002 & [16] \\
\hline \multicolumn{6}{|c|}{ SLCH under low-input agriculture } \\
\hline Cassava & Uganda & & $3.4(0.4-25.8)$ & 2002-2003 & [4] \\
\hline Sweet potato & Uganda & & $0.1(0.0-0.2)$ & 2002 & [4] \\
\hline Onion & Tanzania & & $5.94(2.2-12.18)$ & 2013 & The current study \\
\hline Carrot & Tanzania & & $9.3(2.75-22.86)$ & & The current study \\
\hline Potato & Tanzania & & $1.12(0.7-2.0)$ & & The current study \\
\hline \multicolumn{6}{|c|}{ Water and tillage erosion } \\
\hline Rill erosion & Tanzania & 91 to 258 & & 2000- 2002 & [17] \\
\hline $\begin{array}{l}\text { Interill } \\
\text { erosion }\end{array}$ & Tanzania & 41 to 115 & & 2000- 2002 & [17] \\
\hline $\begin{array}{l}\text { Rill and } \\
\text { inrerill } \\
\text { erosion }\end{array}$ & Tanzania & 132 & & 2010- 2012 & [6] \\
\hline $\begin{array}{l}\text { Rill and } \\
\text { Interrill } \\
\text { erosion }\end{array}$ & Tanzania & 28 to 72 & & 1972 & [18] \\
\hline $\begin{array}{l}\text { Tillage } \\
\text { erosion }\end{array}$ & Tanzania & $\begin{array}{l}42 \text { to } 148 \\
\mathrm{~kg} / \mathrm{m} / \mathrm{yr}\end{array}$ & & $2000-2001$ & [19] \\
\hline Sheet and rill & Belgium & 6.9 & & 1999 & [5] \\
\hline Tillage & Belgium & 8.7 & & 1999 & [5] \\
\hline
\end{tabular}




\section{CONCLUSIONS AND RECOMMENDATIONS}

Significant rates of soil and nutrient losses due to crop harvesting in the Usambara Mountains were revealed. This calls for the need to include SLCH in soil erosion assessment and mitigation strategies to reduce overall soil loss rates. Soil water content played a significant role on variability of SLCH for onion while BD for carrot with minor influence for potato. Soil texture played a minor role in SLCH of the studied crops. Higher SLCH was observed in carrot harvesting followed by onion and potato being the least. Migambo village had higher rates of SLCHspec and SLCHcrop as compared with Majulai.

Soil losses due to crop harvesting can be reduced by avoiding harvesting of crops when soils are wet and sticky. Furthermore, farmers should remove as much as possible soil stuck on the harvested crops at their farm plots instead of cleaning them at their homes and river streams as is usually practiced in Usambara Mountains to avoid losses of soil and nutrients from farm lands and protecting river streams from pollution and sedimentation. An easy way to do this is to let the roots or tubers dry for a couple of days in the field prior to transporting them, as when the soil dries most of it will drop out and remain in the field.

\section{ACKNOWLEDGEMENTS}

The authors are grateful to the VLIR-UOS supported RIP-DSS SUA Project "Enhancing Indigenous Knowledge on Conservation Agriculture for Poverty Alleviation and Sustainable Livelihood, Usambara Mountains, Lushoto, Tanzania", for providing financial and logistical assistance to the research. The first author is grateful to the Tanzania Commission of Science and Technology (COSTECH) for sponsoring $\mathrm{PhD}$ programme that contributed to the production of this paper.

\section{COMPETING INTERESTS}

Authors have declared that no competing interests exist.

\section{REFERENCES}

1. Kimaro DN. Assessment of major forms of soil erosion in the morningside catchments, Uluguru Mountains, Tanzania.
$\mathrm{PhD}$ Thesis, Sokoine University of Agriculture. 2003;292.

2. Ruysschaert G, Poesen J, Verstraeten G, Govers G. Soil losses due to crop harvesting of various crop types in contrasting agro-ecological environments. Agriculture, Ecosystems and Environment. 2007;120:153-165.

3. Ruysschaert G, Poesen J, Verstraeten G, Govers $\mathrm{G}$. Soil loss due to crop harvesting: Significance and determining factors. Progress in Physical Geography. 2004;28:467-501.

4. Isabirye $M$, Ruysschaert $G$, Van linden $L$, Poesen J, Magunda MK, Deckers J. Soil losses due to cassava and sweet potato harvesting: A case study from low input traditional agriculture. Soil and Tillage Research. 2007;92:96-103.

5. Poesen J, Verstraeten G, Soenens R, Seynaeve L. Soil losses due to harvesting of chicory roots and sugar beet: an underrated geomorphic process. CATENA. 2001;43:35-47.

6. Msita HB. Insights into indigenous soil and water conservation technologies in Western Usambara Mountains, Tanzania. $\mathrm{PhD}$ Thesis KU Leuven Belgium. 2013;198.

7. NBS (National Bureau of Statistics). Ministry of Planning, Economy and Empowerment (MPEE). United Republic of Tanzania 2002 Census. Volume X Dar es Salaam; 2006.

8. Moberg JP. Soil and plant analysis manual. The Royal Veterinary and Agricultural University, Chemistry Department, Copenhagen, Denmark. 2001;133.

9. Minitab. Minitab statistical software for quality improvement. Meet Minitab: Minitab User Guide. Minitab Inc. Pennsylvania State University, USA: 2004;134.

10. Genstat. Introduction to Genstat 14 for Windows. Reading, UK: Statistical Service Centre, University of Reading UK. 2011;41.

11. Ruysschaert G, Poesen J, Verstraeten G, Govers G. Interannual variation of soil losses due to sugar beet harvesting in West Europe. Agriculture, Ecosystem and Environment. 2005;107:317-329.

12. Ruysschaert G, Poesen J, Verstraeten G, Govers G. Soil losses due to mechanized potato harvesting. Soil and Tillage Research. 2006;86:52-72. 
13. Turkelboom F, Poesen J, Ohler I, Ongprasert S. Reassessment of tillage erosion rates by manual tillage on steep slopes in Northern Thailand. CATENA. 1999;29:29-44.

14. Van Esch L. Soil losses due to harvesting of carrots (Daucus carota L.). MSc. Thesis, Department of Geography, KU Leuven, Leuven; 2003.

15. Belotserkovsky Y, Larionov A. Removal of soil by harvest of potatoes and root crops. Vestnik Moskovskogo Universiteta Seriia 5. Geografia. 1988;4:49-54.

16. Auerswald K, Gerl G, Kainz M. Influence of cropping system on harvest erosion under potato. Soil \& Tillage Research. 2006;89:22-34.

17. Kimaro DN, Poesen J, Msanya BM, Deckers JA. Magnitude of soil erosion on the northern slope of the Uluguru Mountsins, Tanzania: Interrill and rill erosion. CATENA. 2008;75:38-44.

18. Temple PH. Measurements of runoff and soil erosion at an erosion plot scale with particular references to Tanzania. Geografiska Annaler. 1972;54A:203-220.

19. Kimaro DN, Deckers JA, Poesen J, Kilasara M, Msanya BM. Short and medium term assessment of tillage erosion in the Uluguru Mountains, Tanzania. Soil \& Tillage Research. 2005;81:97-108.

(0) 2015 Mwango et al.; This is an Open Access article distributed under the terms of the Creative Commons Attribution License (http://creativecommons.org/licenses/by/4.0), which permits unrestricted use, distribution, and reproduction in any medium, provided the original work is properly cited.

Peer-review history:

The peer review history for this paper can be accessed here: http://www.sciencedomain.org/review-history.php?iid=651\&id=24\&aid=5963 